\title{
Mütareke Dönemi’nde Pontus Devleti Kurmaya Yönelik Çalışmalar ve Alınan Karşı Önlemler
}

\author{
Yrd. Doç. Dr. Selçuk URAL ${ }^{*}$
}

\begin{abstract}
ÖZET
Mondros Mütarekesi'nin imzalanmasından sonra, Ingiltere azınlıkların Anadolu'da kendi devletlerini kurmak istemelerine destek verdi. Bu yöndeki çalışmalardan biri de Doğu Karadeniz Bölgesi'nde Pontus Devleti kurulmasıydı.

Bu makalede Rum ve Ingilizlerin Pontus Devleti kurmak için yaptığı çalışmalar ile Osmanlı Hükümeti'nin aldığı karşı önlemler ortaya koyulmaya çalışılmıştır.

Anahtar Kelimeler: Ingiltere, Rum, Pontus, Doğu Karadeniz.

The Efforts To Create A Pontus State During The Armistice Period And The Measures Taken

\section{ABSTRACT}

After the Montrose armistice being signed, England supported the will of the minorities to create their own state in Anatolia. One of the activities in accordance with this desire was the creation of the Pontus State in the Eastern Black Sea Region.
\end{abstract}

This study tries to reveal the activities of the Greek and the English creating a Pontus State and the measures taken by the Ottoman Government against these actions.

Keywords: England, Greek, Pontus, Eastern Black Sea.

İtilaf Devletleri, I. Dünya Savaşı'ndan galip çıkınca Mondros Mütarekesi hükümlerinden yararlanarak, Osmanlı Devleti'ni parçalamak için harekete

\footnotetext{
• Kafkas Üniversitesi, Fen-Edebiyat Fakültesi Tarih Bölümü, Kars/Türkiye.
} 
geçtiler. Doğu Karadeniz Rumları da bu paylaşımdan pay kapmak ve doğuda Batum'dan, batıda Sinop'a kadar uzanan topraklar üzerinde bir Pontus devleti kurmak için Kasım 1918'den itibaren gerek bölgede, gerekse Avrupa başkentlerinde yoğun siyasi ve askeri çalışmalar başlattılar. Fakat Rumlar, Türkler karşısında çok küçük bir azınlık durumundaydılar. Üstelik Trabzon üzerinde Ermeniler ile rekabet halindeydiler. Bu sebeplerden dolayı Paris Barış Konferansı Yüksek Konsey üyeleri Pontus hareketine mesafeli yaklaşmaktaydı.

İtilaf Devletleri'nin, Pontus Devleti fikrini sıcak karşılamamalarına rağmen, bölgede görev yapan İtilaf temsilcileri -İngiliz kontrol subaylarımetropolitler ve çeteler eliyle yürütülen çalışmaları desteklediler'. İtilaf temsilcileri bir yandan Rum göçmenlerinin getirilmesine çalışırken, diğer yandan çetelere karşı alınmaya çalışılan önlemleri etkisizleştirmek için yoğun çaba harcadılar. Mustafa Kemal Paşa'nın Harbiye Nezareti'ne ve Sadarete gönderdiği raporlar bu durumu bütün çıplaklığıyla ortaya koymaktaydı ${ }^{2}$. İtilaf temsilcileri, Trabzon'a çok yakında bir Rum valinin geleceğini, Hıristiyanların hukukunun korunması için İtilaf Devletleri'nin barış antlaşmasında gerekli düzenlemeleri yaptığı yönünde propagandalarla Rumları devlet aleyhine kışkırtıyorlardı ${ }^{3}$. Propagandalar iki hedef gözetilerek yapılmaktaydı. Birincisi, Rumların Pontus davasına sahip çıkmalarını sağlamak, ikincisi ise, Batum vs. gibi Kafkas vilayetlerinde bulunan ve Anadolu'ya göç etmekte tereddüt eden Rumları korkulacak bir şey olmadığına ve İtilaf Devletleri’nin güvencesi altında olacaklarına inandırmaktı.

Verilen desteğin ve yapılan propagandaların bir boyutu da Osmanlı makamlarının göçmenler hususunda takındı ğı olumsuz tavrı ortadan kaldırmaktı. Zira Osmanlı makamları göçmenlerin büyük kısmının savaş sırasında bölgeden ayrılanlar olmadığını, aksine bölgenin asayişini ortadan kaldırmayı amaçlayan çeteciler olduğunu düşünmekteydi.

Gizli yollarla bölgeye sokulan silah ve cephaneyle donatılan Rum çeteleri Trabzon'da yavaş yavaş kendilerini göstermeye başladılar. Rum çeteleri özellikle İzmir'in işgal edilmesinden sonra, terör hareketlerine hız verdiler. Yine de Samsun bölgesindeki çeteler kadar etkili olamadılar. Bunun sebebini Karabekir Paşa 24 Ağustos 1919'da Harbiye Nezareti'ne gönderdiği telgrafında belirtmekteydi. Karabekir Paşa, milliyetler arasında herhangi bir sebepten ötürü asayişsizlik meydana gelmediğini, Rum çetelerinin ve propagandacıların tahrik ve teşviklerine rağmen alınan önlemler sayesinde asayișin bozulmasına yol açabilecek bir olaya izin verilmediğini, muhacir

\footnotetext{
' Gotthard Jaeschke, Kurtuluş Savaşı Ile İlgili İngiliz Belgeleri, Ankara 1986, s.58.

2 Raporlar hakkında geniş bilgi için bkz. Atatürk Ile Il gili Arşiv Belgeleri, Ankara 1982, s.27-32, 34-37.

${ }^{3}$ Genelkurmay Başkanlığı Askeri Tarih ve Stratejik Etüt Dairesi Başkanlı̆̆ı Arşivi (ATASE), İstiklâl Harbi Kataloğu, (iSH). K.201, G.143, B.143-1,2.
} 
adıyla gelenlerin silah, cephane vs. askeri malzemeyi vilayete sokmamaları için de hem valilikçe, hem de Kolorduca gerekli önlemlerin alındığını ifade etmekteydi ${ }^{4}$.

Patrikhane, metropolitler ve yerel Rum cemiyet üyeleri aralarında yaptıkları yazışmalarda Pontus Devleti'nin kurulabilmesi için iki hususun titizlikle uygulanmasına karar verdiler:

1-Çeteciliğe fevkalade önem ve hız verilmesi,

2-Asayişin ihlaline çalışılması ve daima Türkler ve hükümet aleyhine şikayetlerde bulunulması.

Bu proğram başarıya ulaştırıldığı takdirde İtilaf Devletleri'nin ve özellikle İngiltere'nin Pontus davasına seyirci kalamayacağını düşünen Pontuscular, bölgenin kargaşaya sürüklenmesi halinde İngiltere veya Yunanistan'ın bir askeri müdahaleye girișebileceğini ve bu sayede Pontus devletinin kurulabileceği öngörmekteydiler ${ }^{5}$. Bunun için Doğu Karadeniz'de büyük ama gizli bir seferberlik başlatıldı. Her köy, kasaba ve şehirde çetelere katılımı sağlamak için büyük gayret sarf edildi. 20 yaşın üzerindeki Rumlar, çetelerin doğal üyesi kabul edildi ${ }^{6}$.

Trabzon vilayetine gönderilecek Rum çeteleri Batum'da İngilizlerin desteğiyle Yunan subaylarınca eğitildi. Çetelerin ihtiyaç duyduğu silah, cephane ve diğer askeri malzemeler Yunan Hükümeti'nce karşılandığı gibi Batum'da bulunan Osmanlı depolarından da faydalanıldı. Bu depolar Batum'un tahliyesi sırasında İngilizlere teslim edilmişti ${ }^{8}$. İngilizlerin depolardaki silahları Rum ve Ermenilere dağıttıkları hem Yakup Şevki Paşa, hem de Karabekir Paşa tarafından Harbiye Nezareti'ne gönderilen pek çok

${ }^{4}$ ATASE, ISH, K 98, G.49, B.49-1.

${ }^{5}$ Başbakanlık Osmanlı Arşivi (BOA), Dahiliye Nezareti Kalem-i Mahsusa Kataloğu (DH-KMS), 49-2/42.

${ }^{6}$ ATASE, ISH, K.867, G.51, B.51-1.

${ }^{7}$ Bu hususla ilgili olarak Karabekir Paşa Yunan Salib-i Ahmer (Kızılhaç) teşkilatının gerek Batum'da, gerekse Trabzon'da çok aktif olarak çalıştığını, Rum çetelerine her fırsatta silah, iaşe ve diğer malzemeleri getirdiğini ve hatta kendilerine ait gemilerle bu çeteleri Karadeniz' in muhtelif yerlerine çıkarmaya çalıştığını, Harbiye Nezaretine gönderdiği telgrafta açıkça belirtmekteydi (BOA, $D H-K M S, 55-2 / 7)$.

${ }^{8}$ Batum işgal eden İngiliz İşgal Kuvvetleri Komutanı 31 Aralık 1918'de Batum Müstahkem Mevki Komutanı Cemal Paşa'ya verdiği notayla silahların Batum'dan çıkarılamayacağını bildirdi: "Mütareke şeraiti mucibince terhis olunacak Osmanlı ordusunun fazla silah ve mühimmatı verilecek talimata göre muamele edilecektir. Binaenaleyh ben fazla esliha ve mühimmatı alacă̆ım. Bundan başka Osmanlı ordusu yalnız asayiş için lüzumlu olduğu kadar kalacak. Batum'daki tekmil Osmanlı kutaatının ellerindeki esliha ve mühimmatı da alacağım. Osmanl askeri silahsız olarak Batum'dan çıkacaktur" (ATASE, ISH, K.5, G.175, B.175-1). 
telgraflarda dile getirildi ${ }^{9}$. Depoların yağmasını önlemek amacıyla silahların Anadolu'ya nakli için çaba sarf edildiyse de, bundan bir sonuç alınamadı. İngilizler, Samsun'u işgal ettikten sonra, Rum çetelerine açıktan silah yardımına başladılar ${ }^{10}$.

Eğitimi ve donanımı tamamlanan çeteler gizli yollarla çoğunluğu Samsun olmak üzere, Trabzon'a ve diğer kıyı bölgelerine çıkarılıyordu. Çetelerin Türklere karşı giriştiği katliamlar, Fener Patrikhanesi ve Rum cemiyetleri tarafından Avrupa kamuoyuna daima farklı tanıtıldı. Fener Patrikhanesi, İtilaf Devletleri temsilcileri nezdinde yaptığı girişimlerde, Rum katliamlarını sözde Türk katliamlarına karşı Rumların kendilerini koruması şeklinde göstermeye çalıştı. Böylelikle Osmanlı Hükümeti, Avrupa kamuoyunda zalim bir yönetim olarak tanıtılmakta ve adım adım İtilaf müdahalesine zemin hazırlanmaktayd $\iota^{\prime \prime}$.

Bölgede görev yapan İtilaf temsilcileri ellerinden geldiğince Rum çetelerinin katliam ve propaganda çalışmalarını cesaretlendiren ve destekleyen tavırlar sergiliyorlardı. Temsilciler İstanbul'daki merkezlerine gönderdikleri telgraflarda, Rum çetelerine karşı silahlanmakta olan Türkleri, Rumları katletmeye hazırlanan taraf olarak göstermekteydiler. Tarafların işbirliği yaparak gerçekleşmesi için gayret sarfettikleri İtilaf müdahalesi 9 Mart 1919'da Trabzon yerine Samsun'a yapıldı ${ }^{12}$.

$\mathrm{Bu}$ olay Rumlar ve Rumlara sempati besleyen İtilaf temsilcileri için sevindirici bir gelişmeydi. Zira çalışmalarını sürdürmeleri halinde, Samsun'a yapılan harekâtın bir benzerinin Trabzon'a da yapılması mümkün gibi gözüküyordu. Bunun ilk işaretleri de yavaş yavaş belirmeye başladı.

\footnotetext{
${ }^{9}$ Bu hususla ilgili olarak Dahiliye Nezareti ile Harbiye Nezareti arasında yapılan bir yazışmayı vermek uygun olacaktır:

"Dahiliye Nazirt Adil Beyden

"Harbiye Nazırı Süleyman Şefik Paşaya

"Batum'daki eslihamızın muhafazasına memur çavuşla itilaf askerleri memurlarının müştereken silahlar mitralyözlere varıncaya kadar Rumlara satmakta oldukları ve Ordu kazasına bu meyanda mitralyöz dahi gönderdikleri 3.Ordu Müfettişliğinin Erzurum vilayetinden gönderilen rapordan anlaşılmışı ve taht-ı muhafazada bulunulan eslihamızın muhafizlar tarafindan satılması ve yabanct ellere geçmesi mahsurlu olup icab edenlere serian talimat ifası. 21 Ağustos 35"

"Dahiliye Nezaretine

"Ingiliz başkumandanlığıyla cereyan eden muharebe neticesinde Batum'daki esliha ve cephanemizin Dersaadete celbi tekarrür ettirilerek celbi esbabına tevessül olunduğunu da bera-ı malumat arz eylerim. 11 Eylül 35

(BOA, DH-KMS, 53-3/23).

${ }^{10}$ ATASE, ISH, K.35, G.46, B.46-15.

${ }^{11} B O A, D H-K M S, 51-2 / 19$.

${ }^{12}$ Mesut Çapa, Pontus Meselesi, Ankara 1993, s.52.

Harbiye Nazırı"
} 
İstanbul'daki Fransız İşgal Kuvvetleri Komutanlığı, Samsun'un işgalinden hemen sonra, Trabzon'daki temsilcisinin raporlarına dayanarak, Osmanlı Hükümeti'ne bir nota verdi. Notada; bölgedeki Osmanlı memurlarının Rumlara katliam yapılması için Türk ahaliyi silahlandırdıkları, bu durumun meydana gelmesi halinde bölgedeki büyük, küçük bütün memurların sorumlu tutacağ ifade ediliyordu. Dahiliye Nezareti 23 Martta bütün vilayet ve mutasarrıflıklara gönderdiği yazıda, böyle bir durumun mevcut olup olmadığını sordu. Eğer böyle bir hal mevcut ise bunun devletin başına büyük sorunlar açacağı ifade ederek, halkı bu yola sevk edenlerin derhal tutuklanmasını istedi. Nezaret, Rumların Türklere karşı bir tecavüzde bulunmaları halinde ise ahalinin müdahalesine fursat verilmeyerek, jandarma ve ordu kuvvetleriyle karşılık verilmesini emretti. Bu yazıya Samsun Mutasarrıflığı ve Trabzon Valiliği'nce 5 Nisanda “Rumlar hakkında katliam icrası için şimdiye kadar hiçbir taraftan İslâm ahali arasında bir kışkırtma olmadığı gibi, böyle bir tasavvur ve temayül de mevcut değildir" cevabı verildi. Bu hususta gerekenlere yeniden emir verildiği de ayrıca ifade edildi ${ }^{13}$.

Samsun'un işgalinden sonra, Giresun'da da Rumlar hareketlenmeye başladı. 8 Mayıs 1919 'da sözde tıbbi malzeme ve doktor taşıyan, fakat gerçekte silah ve komitacı getiren Yunan Kızılhaç gemisi Rumların coşkun tezahüratlarıyla karşılandı. Rumların içinde Osmanlı Hükümeti'ne yakınlığıyla tanınan Metropolit Lavrentios'un da bulunması dikkat çekiciydi ${ }^{14}$. Geminin gelişinden cesaret alan Rumlar, Rum yetimhanesine Yunan Kızılhaç bayrağını çekti. Mahalli makamların bu olay karşısında sessiz kalmaları, Türk ahali tarafından tepkiyle karşılandı. Halk, Dahiliye Nezareti'ne gönderdiği telgrafta mahalli idarenin bayrak olayında kayıtsız kalmasını protesto ederek, gerekli önlemlerin alınmasını istedi ${ }^{15}$. Bu olay Samsun'un işgalinin Pontus devleti kurulması hususunda Rumları ne derece etkilediği ve cesaretlendirdiğini açıkça ortaya koymaktaydı.

Samsun'un işgalinden kısa süre sonra Yunan kuvvetlerinin İzmir'e çıkarılmaları bölgede meydana gelen çete faaliyetlerinin sayısında ve niteliğinde artışa ve değişikliğe yol açtı ${ }^{16}$. Bu güne kadar hırsızlık, gasp ve köylere saldırılar düzenleyen Rum çeteleri bu tarihten itibaren kendilerinde jandarma karakollarına saldıracak cesareti görmeye başladılar. Bu gelişme

\footnotetext{
${ }^{13}$ BOA, DH-KMS, 50-1/79,

${ }^{14}$ Sebahattin Özel, Milli Mücadelede Trabzon, Ankara 1991, s. 43; Çapa, Pontus Meselesi, s.32.

${ }^{15}$ Başbakanlık Osmanlı Arşivi (BOA), Dahiliye Nezareti Şifre Kalemi Kataloğu (DHŞFR), 99/64.

${ }^{16}$ İzmir'in işgaline kadar Samsun Sancağı ağırlıklı olarak faaliyet gösteren Rum çeteleri, bu tarihten sonra Trabzon ve Sivas vilayetlerinde de dikkate değer çalıșmalar yapmaya başladılar (BOA, DH-KMS, 54-2/74).
} 
bölge Rumlarının devlete karşı bir ihtilal çıkarmak niyetinde olduklarını gösteriyordu ${ }^{17}$.

Yunan Kızılhaç'1 İzmir'in işgalinden sonra Trabzon'a sık sık uğramaya başladı. Tıbbi ve iaşe yardımı adı altında bol miktarda silah, cephane vs. askeri malzeme gemilerle kıyılara taşınıyordu ${ }^{18}$. Bunun yanı sıra komitacılar doktor sıfatıyla 3-5 kişilik gruplar halinde karaya çıkartılıyordu. Heyetlerin içerisinde papazların bulunması dikkat çekmekteydi. Alınan istihbaratlardan bu kişilerin gerçekte papaz kisveși altında komitacılar olduğunun ögrenilmesi üzerine Harbiye Nezareti, İstanbul Polis Müdüriyeti ve İstanbul Muhafızlığı'nın uyarılarını dikkate alarak, kolordulara gönderdiği yazılarda; bu kişilerin yakından izlenmesini ve üzerlerinden seyahat izin belgesi çıkmayanların derhal sınır dışı edilmesi talimatını verdi ${ }^{19}$. Verilen emirler doğrultusunda Kolordu da karaya çıkan heyetleri yakından izlemekte ve haklarında bilgi toplamaya çalışıyordu. Buna ek olarak Batum'da kurulan ve Trabzon'daki Rumlarla da yakın ișbirliği içerisinde bulunan Pontus Cemiyeti'nin çalışmaları yakından izleniyordu. Cemiyetin çıkardığı gazetenin bölgeye sokulmaması için ciddi önlemler alındı. Karabekir Paşa, Metropolit Hrisantos'un Kafkasya'daki çalışmalarına büyük önem veriyordu. Çünkü metropolitin çalışmalarını Yunanistan'ın, Osmanlı Devleti aleyhine Gürcistan ile bir dostluk ve ittifak anlaşması yapma planının bir parçası olarak görmekteydi. Zira Rum-Ermeni işbirliğinin Trabzon yüzünden uygulamaya sokulamaması üzerine, hem Yunan Hükümeti, hem de Rum cemiyetleri kendi çıkarları açısından Gürcistan ile işbirliği yapmayı daha uygun buluyorlardı. Rum-Gürcü işbirliğinin olmaması için de görünürde hiçbir engel yoktu ${ }^{20}$.

Yunan Kızılhaç heyetlerinin kısa aralıklarla Trabzon'u ziyaret etmeleri ve Rum ahali ile çok yakın ilişkiler kurması Osmanlı Hükümeti'ni bir takım önlemler almaya itti. Dahiliye Nezareti, Trabzon Vilayeti'ne gönderdiği yazıda; Yunanlıların çalışmalarına kısıtlama getirilmesini ve yardımların bundan sonra valilik kontrolünde yapılmasını emretti ${ }^{21}$. Aslında hükümet bu önlemi almakta geç kalmış bile addedilebilir. Çünkü Yunan Hükümeti, Samsun'da ve İmir'de gerçekleşen işgallerden büyük cesaret alarak Trabzon'u Pontus hareketinin merkezi haline getirmeye çalıșıyordu ${ }^{22}$. Bunun için bölgedeki çetelerin yeniden örgütlenmesini yapmak ve eylemlerini artırmak amaciyla Yunan ordusundan Albay Zimbarakis adlı subayın başkanlığında çeşitli rütbelerde 14 subay Trabzon'a gönderildi ${ }^{23}$.

\footnotetext{
${ }^{17}$ Başbakanlık Osmanlı Arşivi (BOA), Dahiliye Nezareti Emniyet-i Umumiye Asayiş Kataloğu (DH-EUM-AYŞ), 9/11

${ }^{18}$ BOA, DH-KMS, 53-1/21.

${ }^{19}$ ATASE, ISH, K.165, G.22, B.22-1,2.

${ }^{20}$ ATASE, ISH, K.100, G.19, B.19-1.

${ }^{21}$ BOA, DH-KMS, 53-2/74.

${ }^{22}$ BOA, DH-KMS, 49-2/51.

${ }^{23}$ BOA, DH-KMS, 49-2/57.
} 
Bütün bu çalışmalar hiç şüphesiz İngiliz makamlarının bilgisi dahilinde ve onların desteğiyle yapılıyordu. Trabzon'da görevli İngiliz kontrol subayı Yüzbaşı Crawford, hem çetelerin eylemlerine göz yummakta, hem de Rum göçmenlerinin Trabzon'a getirilmesine gayret sarf etmekteydi ${ }^{24}$. Bölgedeki İngiliz subayları, ellerinden geldiği kadar Osmanlı kuvvetlerinin Rum çetelerini takip ve etkisiz hale getirilmesini zorlaştırmaya çalışıyorlardı. Bu yolla İngilizler, bölgede asayişin sağlanmasını zorlaştırdıkları gibi, çetelerin takip edilmemesi yüzünden ortaya çıkan huzursuzluğu gerekçe göstererek mütarekenin 7. ve 24. maddelerinin uygulanmasına zemin hazırlıyorlardı. İngilizler, Osmanlı müfrezelerini engelleyerek aynı zamanda Rumlara, Hıristiyanların koruyucusu olduklarını göstermeye ve dolayısıyla Rumların kendilerine yakınlaşmalarına çalışıyorlardı. İngiliz subaylarının engellemelerine yerel mülki makamların ses çıkarmaması Rumları cesaretlendirdiği de bir vakıa idi. Aslında Dahiliye Nezareti'nin de yerel mülki makamlardan farklı hareket ettiği söylenemezdi. 3 Haziranda Sivas'ta bir Rum çetesinin takibi iki İngiliz subayınca engellenince, nasıl hareket edileceğinin sorulması üzerine Nezaret, yetkilerini kullanmak yerine, durumu 7 Haziranda Hariciye Nezareti'ne bildirerek İngiliz Yüksek Komiserliği nezdinde girişimde bulunulmasını istemekle yetindi ${ }^{25}$. Siyasi yollar kullanılarak Pontus sorununun üstesinden gelinemeyeceği Mustafa Kemal Paşa tarafından bir çok defalar dile getirilmiş olmasına rağmen, uyarılar dikkate alınıp ona göre önlemler alınması yoluna gidilmeyerek, sorunun yine onun müsebbibi tarafından çözülmesi isteniyordu.

Hükümetin zaafının yanı sıra, mahalli mülki makamların da aczinden dolayı Rum çetelerinin mevcudu İngilizlerin de desteğiyle bir ara 25.000'ne ulaştı. Bu rakam şüphesiz ülkenin geleceği açısından çok tehlikeli bir gelişmeyi ifade ediyordu ${ }^{26}$.

İngilizler, Rum çetelerinin faaliyetlerini kullanarak, Anadolu'daki nüfuzlarını artırmak için de çaba sarf ediyorlardı. Merzifon'daki İngiliz kontrol subayı, mülki idareye başvurarak, İngiliz kuvvetlerinin eşkıya takibinde Osmanlı kuvvetlerine yardımcı olabileceğini belirtti. Bu teklif İngilizlere, cebri usullerle giremediği yerlere yardım etme bahanesiyle girme imkanı vereceğinden Dahiliye Nezareti asayişin eldeki kuvvetlerle sağlanmasının doğru olacağını bildirerek teklifi geri çevirdi. Nezaret, yine de kolluk kuvvetlerinin yetersiz kalması durumunda küçük miktarda olması şartıyla İngiliz kuvvetlerinden yararlanılması hususunda açık kapı bıraktı ${ }^{27}$.

İngilizlerin, Rumlar konusunda niyet ve çalışmaları ortada iken bu teklifin uzun vadede Rumların çıkarlarına yarayacağı şüphe götürmez bir

\footnotetext{
${ }^{24}$ Çapa, Pontus Meselesi, s. 53

${ }^{25}$ BOA, DH-EUM-AYS , 11/99

${ }^{26}$ Mustafa Balcıoğlu, Belgelerle Milli Mücadele Sirasında Anadolu'da Ayaklanmalar ve Merkez Ordusu, Ankara, 1991, s.1.

${ }^{27}$ BOA, DH-KMS, 55-1/30.
} 
gerçekti. Çünkü İngiliz kuvvetleri her nereye girmişler ise orada gayri müslim unsurları ön plana çıkaran düzenlemeler yapmışlardı. Şimdi de farklı davranmaları için bir sebep yoktu ${ }^{28}$.

İngilizler Pontus davasına bazı farklı uygulamalarıyla da yardımcı oluyorlardı. Bunların başında Yunan Kızılhaç gemilerinin getirdiği malzemelerin gümrükte Osmanlı memurlarınca kontrol edilmesini engellemek geliyordu. Bu durum özellikle Samsun'da çok sık yaşandığından hükümete sayısız şikayet dilekçesi gönderildi. Hükümet bu uygulamayı durdurmaya yönelik önlem almak yerine, olayları protesto etmekle yetindi.

İtilaf temsilci ve subaylarının Pontus hareketine verdikleri en büyük destek yardım Rum göçmenlerinin bölgeye getirilmesinde yaşandı. İngiliz kontrol subayı Crawford, gerek vilayet nezdinde, gerekse askeri makamlar nezdinde yaptığ ${ }_{1}$ girişimlerle Kafkasya'daki Rumların Anadolu'ya getirilmesine çalıştı. Crawford yaptığı girişimlerini iki sebebe dayandırıyordu. Birincisi, göçmenler savaş sırasında göç etmek zorunda kalan Osmanlı Rumlarıydı. Osmanlı Hükümeti göçmenlerin eski yerlerine iade edilmesini kabul ettiğine göre yerel makamlar bunlara kolaylık sağlamalıydı. İkincisi ise, Kafkasya'da yaşanan açlık ve sefaletti. Göçle ilgili olarak yukarıda ifade edilen sebeplerin dışında başka gerekçeler de ileri sürülüyordu. Bunlardan en ilginci Trabzon Valiliği'nin 17 Mart 1919'da Dahiliye Nezareti'ne gönderdiği yazıda dile getirildi. Rusya'dan Trabzon'a gelen 100 kişilik Rum göçmenleri, Pontus hareketine destek vermediklerinden dolayı 800 kişilik bir Rum çetesi tarafından katliam edilmemek için önce Sohum'a, oradan da Trabzon'a gelmek zorunda kaldıklarını iddia ediyorlard $1^{29}$. Bu iddianın hiçbir doğruluk derecesi yoktu. Tamamen Osmanlı makamlarını aldatmaya yönelik olarak Yunanlılar ve Pontus Cemiyeti'nce başvurulan bir metottu. Trabzon Emniyeti yaptığı araştırma sonucunda iddianın yalan olduğunu ortaya çıkarınca, göçmenlerin kabul edilmemesine karar verildi ${ }^{30}$.

Osmanlı Hükümeti başta olmak üzere bölgedeki mülki ve askeri makamlar temelde Rum göçmenlerin kabul edilmesine karşı değillerse de, göçmen adı altında komitacıların, Balkan Harbi sıralarında göçmüş ve Osmanlı uyruğundan çıkarılmış olan Rumların ülkeye sokulmalarına karşıydı. Rumların sefalet içinde olmaları sorununa gelince; Vilâyât-1 Şarkiye'nin durumu Kafkasya'dan hiçte iyi değildi. 9. Ordu'nun Elviye-i Selâse'yi boşalttığı sırada İngilizlerin erzaka el koyması yüzünden hem ordu, hem de ahali büyük sıkıntı içerisindeydi ${ }^{31}$. Hükümetçe alınan önlemlere

\footnotetext{
${ }^{2 *}$ ALBAYRAK, 25 Ağustos 1335/1919, Nr:24

${ }^{29} B O A, D H-E U M-A Y S, 1 / 41$.

${ }^{31)} B O A, D H-E U M-A Y S, 1 / 43$

${ }^{31}$ ATASE, ISH, K.10. G.14, B.14-1, 2.
} 
rağmen ${ }^{32}$, sorunların halledilemediği bir ortamda büyük miktarda Rum'un getirilmesi iaşe, barınma ve sağlık sorunlarını iyice artıracağından göçmenlerin iadesine sıcak bakılmıyordu ${ }^{33}$. Bunlara rağmen İngilizler, Rum göçmenlerin getirilmesinde ve yerleștirilmesinde 1 srar ediyorlardı. İngiliz Yüksek Komiserliği bunu kendine görev edindiği gibi ${ }^{34}$, çeşitli tarihlerde oluşturduğu heyetlerle de yapılan çalışmaları yerinde görmek amacıyla Karadeniz vilayetlerinde incelemelerde bulundu. İncelemelerin amac1 bölgeye daha fazla Rum'un yerleştirilmesi imkanlarını araştırmak ve bu yönde mahalli idareciler üzerinde bask1 kurmakt ${ }^{35}$.

İngilizlerin bu niyet ve çalışmalarına hükümetin izlediği politikalarla katkı sağlamaktaydı. 4 Mart 1919'da iktidara gelen Damat Ferit Paşa izlediği politikayla İngilizlerin işini kolaylaştırmaktaydı. Amiral Calthorpe 6 Haziran 1919'da Lord Curzon'a gönderdiği telgrafta; Sadrazam Ferit Paşa başta olmak üzere üst düzey Osmanlı yetkililerin kendilerine yakın olmalarının, göçmenlerin Anadolu'ya getirilmesine ve durumlarının iyileştirilmesine iyi bir fırsat verdiğini, bundan da en iyi şekilde yararlanmaya çalıştıklarını yazmaktayd ${ }^{36}$.

İngiliz Yüksek Komiserliği ve onun bölgedeki uzantıları Rum göçmenlerinin getirilmesi projesini İzmir'in işgaline kadar kısmen başarıyla uyguladılar. Samsun'un arkasından İzmir'de gerçekleşen işgal yakın bir

\footnotetext{
${ }^{32}$ Hükümet, Doğu Harekatından sonra başta Trabzon olmak üzere Erzincan Erzurum ve Van'ın, Kars'ın ve Batum'un kurtarılmasından sonra iaşe sıkıntısını halletme başta olmak üzere bir dizi kararlar almış ve uygulamaya sokmuşsa da savaş ortamı içerisinde olumlu sonuçlar alınamamıştır (Selçuk Ural, "Kurtuluştan Mütarekeye Kadar Trabzon Vilayeti'nin Sosyo-Kültürel ve Ekonomik Sıkıntılarını Önlemek Amacıyla Hükümetin Aldığı Tedbirler", Trabzon ve Çevresi Uluslararası Tarih-Dil-Edebiyat Sempozyumu, I, Trabzon 2002, s.567$579)$.

33 ATASE, iSH, K.100, G.19, B.19-1.

${ }^{34}$ İngiliz Yüksek Komiserliği, Osmanlı Hükümetine verdiği bir notada, İngiliz Hükümeti'nin Hıristiyan Osmanlı tebaasının savaş sırasında tehcir ve öldürülmelerinden doğan sorumluluğun uluslararası bir sorun olarak gördüğünü, Rum ve Ermeni muhacirlerin eski yerlerine iade edilmesinin sağlanmayı da komiserliğin görevleri arasında zikretmekteydi (Başbakanlık Osmanlı Arşivi (BOA), Bab-ı Âlı̂ Evrak Odası (BEO), 346480).

${ }^{35}$ Ingiliz Yüksek Komiserliğinin emriyle, İngiliz ordusuna mensup Binbaşı Smith ile Deniz Yüzbaşısı Slayt'tan oluşan bir İngiliz heyeti 6 Temmuz 1919 'da muhacir ve mülteci durumunu incelemek amacıyla Sinop'ta incelemeler yaptı. Binbaşı Smith, burada askeri ve mülki amirlerle yaptığı görüşmede Rusya'dan gelmekte olan Rum muhacirlerin Trabzon başta olmak üzere bütün Karadeniz bölgesinde iskân ettirilmesinin İngiliz Hükümetinin bir politikası olduğunu ima etmiştir. 20. Kolordu Kumandanı Ali Fuat Paşa heyetin bu amaç dışında Bolşeviklerin Batum ve civarını tazyik etmeleri üzerine bu durumun Karadeniz sahillerine tesirini öğrenmek ve Müdafaa-i Hukuk-1 Milliye teşkilatlarıyla ahali elinde silah bulunup bulunmadığın önlemek istediklerini yazmaktadır. Ali Fuat Paşa, heyetin 15 gün sonra tekrardan Trabzon'dan Sinop'a kadar bütün Karadeniz kıyılarını inceleyeceklerini belirtmekteydi. (ATASE iSH, K.47, G.18, B.118-1,2,3).

${ }^{36}$ Bilal Şimşir. Ingiliz. Belgelerinde Atatürk, I, Ankara 1975, s.6.
} 
zamanda Trabzon'un ve Erzurum'un da başına gelebileceğinden endișe edilmesine yol açtı. İzmir'in işgalinden sonra göçmenlerin getirilmesi için yapılan ısrarlar bu planın bir parçası olarak görülmeye başlandı. Bu sebepledir ki bu tarihten sonra Osmanlı mülki ve askeri makamları İngilizlerin isteklerini uygulamak hususunda hiç istekli davranmadılar. Bu durum Yüksek Komiserlik subaylarından Albay İan Smith'in 1-13 Temmuz 1919'da Doğu Karadeniz'de gerçekleştirdiği gezisinde bütün çıplaklığıyla ortaya çıktı. Albay Smith hazırladığı raporunda; Türk ve Rumların birbirleri aleyhine devamlı suretle silahlandıklarını, jandarmanın yetersiz olması sebebiyle çetelerin çok rahat hareket ettiklerini, Yunanlıların İzmir'de yaptıkları katliamlardan cesaret alan Rumların Pontus devleti kurmak için yaptıkları siyasi ve askeri propagandaların Türkleri oldukça rahatsız ettiğini belirtmekteydi ${ }^{37}$. Durumun bu noktaya geleceği Haziran başlarında Hurst'un Samsun Sancağı'nda yaptığı inceleme gezilerinde kendini göstermişti. Yüzbaşı Hurst, 12 Haziranda Amiral Calthorpe'a verdiği raporda; Rumlu propagandası ve çete çalışmalarının Osmanlı makamları ve Türkler arasında huzursuzluğu artırdığını, durumun her geçen gün kötüleştiğini ve özellikle Laz çetelerinin sayısında ciddi bir artışın tespit edildiğini ifade etmekteydir ${ }^{38}$.

Doğu Karadeniz'de Rum nüfusunun artırılma çabaları sadece dışarıdan Rumların getirilmesiyle sağlanmıyordu. İç ve Güney Anadolu'daki Rumlar el altından Batı Anadolu'ya ve Doğu Karadeniz'e kaydırılıyordu ${ }^{39}$. Bunun yanı sıra Elviye-i Selâse'nin Kars ve Sarıkamıș taraflarında bulunan Rum köyleri de aynı şekilde Batum üzerinden Doğu Karadeniz'e sevk ediliyordu ${ }^{40}$. Bu göçlerin her geçen artma eğilimi göstermesi üzerine 1 Eylül 1919'da Harbiye Nazırı Süleyman Şefik Paşa, Dahiliye Nezareti'ne gönderdiği yazıda; Elviye-i Selâse'den göç ettirilerek, Doğu Karadeniz başta olmak üzere İzmir ve İstanbul'a yerleștirilmesi planlanan Rumların kesinlikle kabul edilmemelerini istedi ${ }^{41}$. Bunların dışında Yunan Hükümeti'nin de Rum nüfusunu artırma planı çerçevesinde A.B.D.'deki yaklaşık 5000 Yunanlı'yı Yunanistan üzerinden Anadolu'ya getirmek için çalışmalar yaptığı 17 Aralık 1919'da Fransız Bastar gazetesi tarafından iddia edilmekteydi ${ }^{42}$.

1919 yılı sonbaharından itibaren bir yandan Trabzon Vilayeti'ne Rum göçü devam ederken, diğer yandan da Trabzon Vilayeti'nden Batum'a ve diğer bölgelere tersine göç bașladi. Bunun sebebi artan Rum göçüne karşın iaşe ve barınmada yaşanan sıkıntıların had safhaya ulaşmasıydı. Diğer bir

\footnotetext{
37 Şimşir, Ingiliz Belgelerinde Atatürk, I, s.51-52.

38 Şimşir, Ingiliz Belgelerinde Atatürk, I, s. 16-22.

39 BOA, DH-KMS, 49-2/42.

+0 Başbakanlık Osmanlı Arşivi (BOA), Dahiliye Nezareti Idare-i Umumiye Kataloğu (DH/I-UM), 20-17/12-60.

${ }^{41}$ BOA, DH-KMS, 54-3/33.

42 Harbiye Nezareti'nden Sadaret'e gönderilen 18 Aralık 1919 tarihli tezkere (Harp Tarihi Vesikaları Dergisi (HTVD), Sayı 12 (Haziran 1955), Belge No (BN):317).
} 
ifadeyle Pontus Devleti'ni kurmak için getirilen Rumlar, hamileri tarafından evsiz ve yiyeceksiz bir halde, kendi kaderlerine terkedilmişti. Göç hareketi Kolordu tarafından yakından izlendi. Gidenlerin miktarının yanı sıra, bunların yerli ya da yeni gelenler mi olduğu tespit edilmeye çalışıldı ${ }^{43}$. Göçlerin İngilizlerin Samsun'u boşalttığı tarihte başlaması ve her geçen gün artması, göçün arkasında siyasi bir amacın var olduğunu gösteriyordu. Karabekir Paşa göçün arkasında iki sebebin yattığını savunmaktaydı. Birincisi, Rumlar arasında "Pontus Devleti" kurulacağı yönündeki inancın zayıflaması göçte etkili olmuştu. İkinci sebep ise İngilizlerden kaynaklanıyordu. İngilizler, Anadolu'dan çekilmeye başlamalarına karşın, Kafkasya'ya ve özellikle Batum'a Türk nüfuzunun sirayet etmesini engellemek için Rumları Batum'a yerleştirmeye çalışıyordu. 1 Temmuz-18 Ekim 1919 tarihleri arasında sadece Trabzon Vilayeti'nden 1840 Rum ülkeyi terk etti. Bunlar, seyahat belgesi alarak gidenlerdi. Belgesiz gidenlerin on binler civarında olduğu tahmin ediliyordu ${ }^{44}$. Fakat İngilizler ve Pontus Cemiyeti bu olayı da çarpıtarak "Türkler, Rumlara zulüm ediyor", "Rumlar katliamlara maruz kalmamak için evlerini terk ediyor", "Bölgede asayişsizlik var” şeklinde göstermeye çalışıyorlardı. Aynı kesimler, Samsun'un Rum ve Ermeni mahallelerinde silah aranmasını Hıristiyanlara katliam yapılacağı şeklinde yansitarak, felaket tellallığı yapmaya başladılar ${ }^{45}$. Amiral Robeck, Lord Curzon'a 11 Kasım 1919'da gönderdiği raporunda; iç kesimlerden kıyılara ve buradan da Kafkasya'ya yapılan göçü Milli Mücadele'nin gelişimine bağlanmaktadır. Robeck, milli teşkilatların göçmenlerin iç kesimlerde barınmasını engellediğini, onları ev ve iaşe sıkıntısının had safhada olduğu kıyı kesimlerinde birikmeye zorlayarak göçe mecbur ettiğini iddia etmekteydi. Amiral Robeck, yardım komitelerinin yaptıkları çalışmaların yetersizliğinin yanı sıra mahalli makamların göçmenlerin mallarını iade etmekte isteksiz davranmasının göçün artmasına etki ettiğini öne sürmekteydi ${ }^{46}$. Zira Samsun Mutasarrıfı Hamid Bey, İngiliz kontrol subaylarından Yüzbaşı Perring ile yaptığı bir görüşmede; Türklerin büyük sıkıntılar içerisinde olduğunu, Türk köylerinin Rus işgali yüzünden harap bir hale geldiği bir ortamda İtilaf Devletleri'nin Hıristiyanlara ait malların iadesinde ısrar etmesinin taraftar arasında büyük çatışmalara yol açabileceğine dikkat çekerek, bu hususta fazla ısrar etmemelerini tavsiye etti ${ }^{47}$.

Hamid Bey'in şahsında bütün mülki makamların Rum göçmenlerinin iskanı ve mallarının iadelerine soğuk bakmasının sebebi Rum düşmanlığından ziyade, bu uygulamalar sonucunda Türk göçmenlerinin

\footnotetext{
${ }^{43}$ BOA, DH-KMS, 53-3/64.

${ }^{44}$ ATASE, iSH, K.98, G.66, B.66-4.

${ }^{45}$ Şimşir, Ingiliz Belgelerinde Atatürk, I, s.159-160.

${ }^{46}$ Şimşir, Ingiliz Belgelerinde Atatürk, I, s.198.

${ }^{47}$ Yüzbaşı Perning'in Amiral Webb'e gönderdiği 24 Ağustos 1919 tarihli rapor (Şimşir, Ingiliz Belgelerinde Atatürk, I, s.95).
} 
haddinden fazla mağdur olmalarıydı. Bilindiği gibi savaş esnasında Rumların ve Ermenilerin boşalttığı köylere Kafkas Cephesi'nden ve diğer bölgelerden gelen Türkler yerleştirilmişti ${ }^{48}$. Bunların sayısının 1.000 .000 civarında olduğu göz önüne alınırsa, mahalli makamların Türk göçmenlerinin iaşe ve barınma sorununu tam olarak halletmeden, Rum ve Ermenilere ait malları iade etmekte istekli davranmamalarının sebebi kendiliğinden ortaya çıkmaktayds ${ }^{49}$.

Samsun'un İngiliz, İzmir'in de Yunan kuvvetleri tarafından işgal edilmesi Osmanlı Hükümeti'nin Doğu Karadeniz'de bir Pontus Devleti'nin kurulmak istendiği yönündeki endişelerini kuvvetlendirdi. Buna meydan vermemek amacıyla ilk önce Rum göçmenlerinin resmi teşkilatlar eliyle eski yerlerine iadeleri çalışmaları durduruldu ${ }^{50}$. Arkasından bağımsız kuruluşlar tarafından göçmenlere yapılan yardımlara bir çeki düzen vermek ve vilayetlerin daha aktif rol almasını sağlamak için yardımların valiliklerin kontrolünde yapılmasına karar verildi. Bundan sonraki adım özellikle Kordos Cemiyeti'nin göçmen adı altında Karadeniz kıyılarına sevk ettiği Rumların sıkı bir şekilde denetlenmesi için valiliklere emir verilmesiydi. Dahiliye Nezareti gönderdiği yazıda hükümet tarafından verilen seyahat belgesini taşımayan Rumların vilayetlere kabul edilmemesini istedi ${ }^{51}$. Bütün bu emirler göçü ve buna bağlı olarak vilayette yapılan yardım çalışmalarını kontrol altına almaya yönelikti. Her ne kadar hükümet kendi teşkilatlarıyla , göçmenlerin eski yerlerine iade çalışmalarını durdurmuşsa da, gayri resmi teşkilatların yürüttükleri çalışmaları yasaklamamıştı. 12 Haziran 1919'da Giresun'da meydana gelen olay bunun en iyi ispatıydı. Bu tarihte bir Yunan gambotu Batum yönünden Giresun'a geldi. Giresun metropoliti ve kaymakam Yunan komutanını ziyaret etti. Yunan komutanı görüşme sırasında görevlerinin Rusya'da Bolşevik tehdidi sebebiyle hayatlarından endişe eden Rumların vatanlarına dönmelerini sağlamak olduğunu söyledi. Ayrıca Yunanistan'ın bölgeyle ilgili olarak bir emel beslemediğini, Türklerle Rumların bir arada yaşamalarını arzuladığını ifade etti. Dahiliye Nezareti, bu gelişmeyi dikkate alarak 15 Haziranda Trabzon Vilayeti'ne gönderdiği yazıda; Yunanlıların vilayet içerisinde huzursuzluk çıkarmak istediğini, bunun önlenmesi için hükümetin elinden gelen her türlü çabayı harcadığını belirttikten sonra, gelenlerin miktarlarının, hüviyetlerinin tespit edilerek, ne amaçla geldiklerinin iyice incelenmesini ve durumlarında bir sakınca görülmezse kabul edilmelerini istedi ${ }^{52}$.

48 Osmanlı Belgelerinde Ermeniler, (Başbakanlık Osmanlı Arşivleri Genel Müdürlüğü Yayını), Ankara 1994, s.248.

${ }^{49}$ Osmanlı Belgelerinde Ermeniler, s.212.

5) $B O A, D H$-ŞFR, 91/150.

${ }^{51}$ BOA, DH-SFR, 97/87.

${ }^{52}$ BOA, DH-KMS, 53-2/74 
Trabzon'daki İngiliz temsilcisi, Rusya'daki sefaleti gerekçe göstererek Güney Rusya'dan gelen 500 Rum göçmeninin kabul edilmesini istedi ${ }^{53}$. Trabzon Mevki Komutanı ve vali göçmenlerin kabul edilmesi halinde vilayet dahilinde sefaletin artacağına karar vererek isteği geri çevirdi ${ }^{54}$.

Hükümet aldığı kararlarla ve uygulamalarla göçü kontrol altına alamayınca, Güney Rusya'dan gelen ve Osmanlı uyruğundan olmayan Rumların ülkeye girişlerini yasaklama kararı aldı. Meclis-i Vükela, Harbiye Nezareti'nin gönderdiği tezkere çerçevesinde, hangi sebeple olursa olsun Güney Rusya'dan göç eden Rumların Trabzon Vilayeti'nin iaşe ve asayişi üzerinde olumsuz etki yapmakta olduğunu göz önüne alarak, ülkeye kabul edilmemelerine ve İtilaf Devletleri Yüksek Komiserlikleri'nin de bundan haberdar edilmesine karar verdi ${ }^{55}$. Meclis-i Vükela'nın kararı Trabzon Vilayeti'ne gönderilen 18 Haziran tarihli telgrafta şöyle ifade edildi: "Rusya tarafından gelip Trabzon ile alakası olmayan ve Yunan tâbiliğine haiz bulunan ve bir maksat-ı siyasiye mïsteniden hicret ettirildikleri anlaşılan eşhasın suret-i kâfiyede kabul edilmeyeceği, Trabzonlu Rumlara gelince bunların avdetlerine mukaddema müsamaha olunmuşsa da mesken ve iaşe buhrant dolayıstyla hal-ı hazırda bunların dahi avdetleri tecviz olunamayacă̆ı ve hükümetin bu babdaki nokta-ı nazarına müzaheret olunarak Trabzon'daki mümessillere talimat ilanıyla, düvel-i İtilafiye mümessillerine işâr kulınmıştır. Hükümetin emr-i lazime-i kat'i bulunduğu cihetle oradaki mümessillerin beyanatına bakslmayarak ve emr-i hükümete itaatleri labed bulunan kaymakamliklara da evamir-i kat'iye verilerek vesait-i mümküne ile Rumların Trabzon'a çıkmamalarının temini ehemmiyetle matlubdur" ${ }^{\prime 56}$.

Nezaret, 22 Haziranda gönderdiği ikinci telgrafta ise; Güney Rusya'dan gelenler ve gelecekler içerisinde Trabzon Vilayeti'nden göçmüş Rumların olabileceklerine dikkat çekerek, bu sıfatı taşıyan göçmenlere herhangi bir engel çıkarılmayarak kabul edilmelerini emretti ${ }^{\xi 7}$. Böylelikle Güney Rusya'dan gelen bütün Rumlara bir yasak getirilmediği, aksine Osmanlı uyruğundan olanların kabul edilmeye devam edileceği açı biçimde ortaya koyuldu. Bunlara karşın Nezaret 26 Temmuzda, her ne sıfat ve yetkiye dayanırsa dayansın herhangi bir makam ve yetkilinin alınan kararlarla çelişen tekliflerinin uygulanmamasını ilgili vilayetlere bildirdi ${ }^{58}$.

Hükümetin aldığı önlemler sadece Rum göçmenleriyle sınırlı kalmadı. Kordos Cemiyeti'nin ihtilal çıkarmaya yönelik çalışmalara hız verdiği ve kıyılara silahlı çeteler çıkardığı yönünde istihbaratlar alınıyordu. Erzurum

\footnotetext{
${ }^{53}$ ATASE, ISH, K.100, G.19, B.19-1.

${ }^{54}$ ATASE, ISH, K.201, G.65, B.65-1.

${ }^{55} B O A, B E O, 345705$.

${ }^{56} B O A, D H-S ̧ F R, 100 / 142$.

${ }^{7}$ BOA, DH-ŞFR, 100/163.

${ }^{58} B O A, D H-S F R, 101 / 38$.
} 
Valiliği 15. Kolordu Komutanlığı'ndan gönderilen yazıya istinaden 31 Temmuz 1919'da Dahiliye Nezareti'ne gönderdiği telgrafta; Rumların Pontus Hükümeti'ni kurmak amacıyla Trabzon'a çok miktarda çete sokmaya çalıştıklarını bildirdi ${ }^{59}$. Bu haber üzerine, hükümet vilayet ve sancaklara gönderdiği bir yazıda; İtilaf ve özellikle Yunan gemilerinin yakından izlenmesini, durumlarından şüphelenilenlerin karaya çıkarılmaması talimatını verdi. ${ }^{60} \mathrm{Bu}$ arada Harbiye Nezareti de, Sadaret'e gönderdiği bir tezkerede; Batum'da toplanan ve Kızılhaç heyetleri adı altında Karadeniz sahillerine çıkarılmaya çalışılan Rum çetelerinin engellenmesi için vilayetlerin gerekli önlemleri almasını ve 15. Kolordu'ya yardımcı olmalarını istedi ${ }^{6 !}$.

Alınan önlemlere rağmen, küçük miktarlarda Rum çeteleri gizli yollarla bölgeye girmekteydi. Harbiye Nezareti 25 Mart 1919'da 3. ve 15. kolordulara gönderdiği yazıda; karaya çıkmayı başaran çetelerin herhangi bir eyleme girişmeden yakalanmaları için süratle ve şiddetle hareket edilmesini emretti $^{62}$.

Hükümet, bir yandan çeteleri ve bunlara ait silahları ele geçirmeye gayret ederken, diğer yandan da Hıristiyanlara karşı Anadolu'da katliam yapılmakta olduğu yönündeki propagandaları ve bunun Avrupa kamuoyu üzerindeki olumsuz etkilerini yok etmeye çalışıyordu. Zira hükümetin Rum göçünü kontrol altına alma çabalarından rahatsızlık duyan kesimler (özellikle taşradaki İtilaf Subayları ve Anadolu'daki Yüksek Komiserlikler ile azınlık temsilcileri) çeşitli araçlarla Hıristiyanların hayatlarının tehlikede olduğu yönünde gerçek dışı propagandalar yaparak İtilaf Devletleri'ni ve Paris Barış Konferansı'nı etkilemeye çalışıyorlardı. Harbiye Nazırı Cemal Paşa, 16 Ekim 1919'da 1. Kolordu Komutanlığı'na gönderdiği yazıda bu tür haberlerin tekzibi ve propagandaların sonuçsuz bırakılması için devamlı suretle çalıştıklarını, fakat kolordularında hükümete destek olacak şekilde karşı propagandalar yapması gerektiğini ifade ederek, takip edilmesi gereken hususları şöyle sıralamaktaydı:

1-Ordu siyasetle değil, yalnız asayişin korunmasıyla uğraşmaktadır.

2-Hıristiyanların hayat, mal ve hukukları kanunlarla güvence altında olup, bunlara karşı hiçbir hareket mevcut değildir.

3-Milli Mücadele Hareketi ve milli teşkilatlar milletin sinesinden doğmuştur. Ordu ile ilgisi olmadığı gibi, İttihatçılıkla da ilgisi yoktur.

Cemal Paşa, bu hususların tesadüf edilen her yabancıya ve taşradaki İtilaf temsilcilerine anlatılmasını, hatta mümkün olursa gayri müslimlerin

\footnotetext{
${ }^{59}$ BOA, DH-KMS, 53-3/15.

${ }^{61}$ BOA, DH-KMS, 49-2/29.

${ }^{6}$ HTVD, Sayı:9 (Eylül 1954), BN:198, 202.

${ }^{62}$ BOA, DH-KMS, 49-2/2.
} 
imzasıyla İstanbul basınına veya yabancı ülkelere asayişin iyi olduğu hakkında telgraflar çekilmesini istedi ${ }^{63}$.

18 Aralık 1919'da, İngiliz ve Yunanlıların desteğiyle Batum'da Sarraf Yuvanidis Efendi'nin başkanlığında Pontus Rum Hükümeti'nin kurulduğu ilan edildi ${ }^{64}$. Aynı gün Harbiye Nezareti, Sadaret'e gönderdiği tezkerede; Yunan Hükümeti'nin Amerika ve Güney Rusya Rumlarını Doğu Karadeniz ile Batı Anadolu'ya yerleştirmek niyetinde olduğunu belirterek, gerekli önlemlerin alınmasını istedi. Meclis-i Vükelâ'da tezkere tartışmaya açılarak Rumların iaşeleri için ülkenin ekonomik durumunun uygun olmadığına ve gelenlerin asayiş açısından büyük sakıncalar doğuracağına kanaat getirilerek, göçmenlerin yetkili makamlarca geldikleri yerlere iade edilmelerine ve bu hususta İtilaf komiserlikleri nezdinde Hariciye Nezareti tarafından lazım gelen girişimlerde bulunulmasına karar verildi. Böylelikle hükümet bu kararla Mart 1919'dan beri kısıtlamaya çalıştığı Rum göçünü tamamen yasakladi ${ }^{65}$.

Hükümet, çetelerin eylemlerine engel olmak için Rumların silahsızlandırılmasına karar verdi. Bu karar doğrultusunda 2000'ni aşkın silah ile 1.200.000 civarında mermi toplandı. Silahsızlandırma çalışmaları Rumların tepkisine yol açtı. Silahlarını teslim etmeye yanaşmayan Rumlar dağlara kaçarak, çetelere katılmaya başladı. Hükümet her geçen gün sayıları artan Rum çetelerini ileride bir Türk-Rum savaşına yol açmasını engellemek ve hükümet otoritesini bölgede yeniden tesis etmek amacıyla sık sık "af" mekanizmasını işletti. Bu sayede Samsun bölgesinde epeyce bir ilerleme sağland ${ }^{66}$. Çıkarılan aflardan Türk çeteleri de faydalandı. Bunlardan birisi de Giresun'da faaliyet gösteren Topal Osman Ağa ve çetesiydi. Topal Osman A ğa Temmuz 1919'da çıkarılan af sayesinde dağdan indi. Osman A ğa Giresun belediye başkanlığına getirildikten sonra, aldığı önlemler sayesinde Giresun'a yapılan Rum göçlerini durdurduğu gibi, Rum çetelerinin eylemlerinde de gözle görülür bir azalmaya sebep oldu. Fakat Osman A ğa'nın yaptığı mücadele İngiliz makamlarının tepkisine yol açmakta gecikmedi. İngiliz Yüksek Komiserliği, Trabzon temsilcisi Popovel'e gönderdiği yazıda; “Derhal Giresun'a giderek Osman A ğanın Hiristiyanlar hakkında tatbik ettiği mezalime dair tahkikat yapılmasını" istedi ${ }^{67}$. İstanbul'un işgal edildiği günlere rastlayan bu emrin bölge için kötü sonuçlar doğurabileceğinden endişe eden Vali Hamid Bey, İngiliz temsilcisinin yanına giderek "Ciddi ve doğru bir tahkikat yapmak arzusunda ise beraber

${ }^{63}$ HTVD, Sayı:9 (Eylül 1954), BN:217.

${ }^{64}$ Mahmut Goloğlu, III. Meşrutiyet, Ankara 1970, s.17.

ts HTVD, Sayı:13 (Eylül 1955), BN:322.

${ }^{6{ }^{6}}$ Hamit Bey, Defter-i Hattrat, s.126, 129

${ }^{67}$ Popovel. Hamit Beyin Trabzon Valiliğine başladığı günlerde Samsun Siyasi Temsilcisi Yüzbaşı Perring nezdinde yaptığı şikayetler neticesinde görevden alınan Yüzbaşı Crawford'un yerine Trabzon'da görev yapan İngiliz kontrol subayıdır (Hamid Bey, Defter-i Hattrat, s.159). 
gitmelerini" teklif etti. Popovel biraz tereddüt ettikten sonra, öneriyi kabul etti. Hamid Bey, incelemenin olumsuz sonuçlanmasını engellemek için, Giresun Kaymakamı Galip Bey'i önceden arayarak, gerekli önlemleri almasın istedi $^{68}$.

Hamid Bey ve Popovel 18 Mart 1920'de Nambago (?) adlı İngiliz torpidosuyla Giresun'a ulaştılar ${ }^{69}$. Kaymakam Galip Bey, verilen talimatı harfiyen yerine getirdiğinden ifadesine başvurulan Hıristiyanların tamamı Osman A ğa lehinde konuştu. Pek iyi geçindiklerini, şikayeti gerektirecek hiçbir şey olmadığını söylediler. Hamid Bey ve Popovel ruhani reisler ve şehrin ileri gelenleriyle de görüştü ${ }^{70}$. Yapılan incelemeler sonucunda Popovel, Trabzon'a varınca suçlamaları yalanlayan bir rapor düzenleyerek, meseleyi kapattı ${ }^{71}$.

Hükümetin aldığı siyasi önlemlere ek olarak, 15. Kolordu Komutanlığı da askeri önlemleri yürürlüğe koymakta gecikmedi. Tortum'da bulunan 3 . Kafkas Tümeni, Pontus hareketini ve özellikle çeteleri durdurmak amacıyla Trabzon'a nakledildi ${ }^{72}$. Bunun yanı sıra Rum çetelerince üs haline getirilmeye çalışılan Santa yaylasında askeri posta görevlendirilerek çetelerin hareket alanı daraltıldı. Bu önlem sayesinde çetelerin teslim olması sağlanarak, muhtemel katliamların önüne geçildi ${ }^{73}$. Karabekir Paşa, Türklerin haklarını siyasal alanda savunmak amacıyla kurulmuş olan Trabzon Muhafaza-1 Hukuk-1 Milliye Cemiyeti'nin bölgenin en ücra köşelerine kadar yayılmasında etkin çalışmalar yaptı ${ }^{74}$.

15. Kolordu Komutanlığı, Trabzon sahillerine çıkarak bölgede huzursuzluk çıkarmak isteyen çetelere karşı aldığı önlemlerden birisi de mevcut jandarma teşkilatını gönüllüler yoluyla kuvvetlendirilmesiydi ${ }^{75}$. Bu çalışmalar 9. Ordu Müfettişi Mustafa Kemal Paşa tarafından da desteklendi ${ }^{76}$.

Pontus Devleti kurulmasına karşı alınan önlemler, İstanbul'un işgalinden sonra Ankara'da açılan TBMM ve hükümeti tarafından da sıkı sıkıya uygulandı.

\footnotetext{
${ }^{6 s}$ Hamid Bey, Defter-i Haturat, s.162-163

${ }^{6}$ ATASE, ISH, K.418, G.171, B.171-1, 2.

${ }^{70}$ Hamid Bey, Defter-i Haturat, s.163.

${ }^{71}$ ATASE, ISH, K.315, G.113, G.113-2.

${ }_{72}$ ATASE. ISH, K.40, G.66, B.66-1.

${ }^{73}$ Mustafa Balcıoğlu, iki i isyan Bir Paşa, Ankara 2000, s.78-79.

${ }^{74}$ Kâzım Karabekir, İstiklâl Harbimiz, I, İstanbul 1993, s.51-53; Kâzım Karabekir, İstiklâl Harbimizin Esasları, İstanbul 1990, s.31.

${ }^{75}$ BOA, DH-KMS, 49-2/2.

${ }^{76}$ Geniş bilgi için bkz: Erdal Aydoğan, "Mustafa Kemal Paşanın Samsun Bölgesinde Jandarma Birlikleri Olușturma Çabaları", 19 Mayıs ve Milli Mücadelede Samsun Sempozyumu, Samsun 2000. s.17-25.
} 


\section{SONUÇ}

Mütarekenin içerdiği hükümlerden yararlanarak, Doğu Karadeniz'de bir Pontus Devleti kurmak isteyen Rumlar, bölgede görev yapan İtilaf kontrol subaylarının desteğiyle siyasi ve askeri çalışmalar yaptılar. Bir yandan göçmenler, diğer yandan da yardım malzemesi adı altında silah ve cephane bölgeye sokulmaya çalışıldı.

Osmanlı Hükümeti, Samsun ve İzmir'in işgalinden sonra, Pontus Devleti'nin kurulmaması için ciddi önlemler almak için harekete geçti. Önce göçü kontrol altına almaya çalıştı. Bölgeye yapılan yardımların valiliklerce denetlenmesi ve dağıtılması hususunda bir dizi uygulamalar başlattı. Fakat istenen sonuçların elde edilememesi üzerine hükümet, hangi sebebe dayanırsa dayansın Rumların bölgeye kabul edilmemesine karar verdi. Çetelere karşı da bir takım mülki ve askeri önlemler alındı. Bunlar sayesinde Pontus hareketinin genişlemesi ve kuvvetlenmesi engellendi. Yine bu önlemler sayesinde çetelerin Türklere karşı katliam yapması engellendi. Böylelikle Rumların 1916 yılına geri dönme çabaları sonuçsuz bırakıldı.

Pontus hareketine karşı verilen mücadele Ankara'da TBMM'nin açılmasından sonra da devam etti ve 1921 yılında başarıyla sonuçlandırıldı. 